\title{
Nalidixic acid mutual prodrug: synthesis and evaluation
}

\author{
Asif Husain $^{\mathrm{a} *}$, Aftab Ahmad ${ }^{\mathrm{b}}$ and Shah Alam Khan ${ }^{\mathrm{c}}$

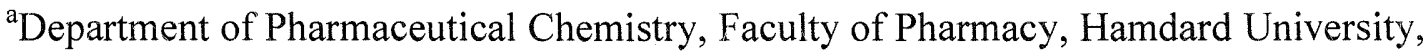 \\ New Delhi-110062, India, Email: drasifhusain@yahoo.com, \\ ahusain@jamiahamdard.ac.in \\ b Jeddah Community College, King Abdul Aziz University, Jeddah 21589, Kingdom of \\ Saudi Arabia \\ ${ }^{\mathrm{c} D e p a r t m e n t ~ o f ~ P h a r m a c y, ~ O m a n ~ M e d i c a l ~ C o l l e g e, ~ M u s c a t, ~ S u l t a n a t e ~ o f ~ O m a n ~}$
}

\begin{abstract}
The aim of this study has been to design a useful drug, which may act with effectiveness both on the gram-positive and gram-negative bacteria (broad-spectrum). An amide-based mutual prodrug (NA-SN) was been prepared following a single-step synthesis by condensing sulfanilamide with nalidixic acid. The compound (NA-SN) was evaluated for in-vitro antibacterial activity against some selected bacteria with significant results. Hydrolysis kinetics of the mutual prodrug were also studied in acidic and basic buffers. The present study reveals the pharmaceutical potential of mutual prodrugs.
\end{abstract}

KEY WORDS: Sulfanilamide, quinolone, kinetics, antibacterial.

\begin{abstract}
RESUMO
O propósito do presente estudo foi o desenvolvimento de um fármaco útil e de amplo espectro efetivo sobre bactéria gram-positivas e gram-negativas. Um pró fármaco baseado em amida (NA-SN) foi preparado numa síntese de somente uma etrapa através da condensação de sulfanilamida com ácido nalidixico. O composto( NA-SN) foi avaliado in-vitro e a sua atividade anti-bacteriana foi significativa. A cinética da hidrólise do pró fármaco mútuo foi estudada em tampões ácidos e básicos. O presente estudo revela o potencial farmacêutico de pró farmácos mútuos.
\end{abstract}

PALAVRAS CHAVE: Sulfanilamida, Quinolona, Cinética, Anti-bacterial 
SOUTH. BRAZ. J. CHEM., Vol.22, No. 22, 2014

Nalidixic Acid Mutual Prodrug

48

\section{INTRODUCTION}

Prodrug has been the concept of retro-metabolic drug design that considers targeting, metabolism, duration of action, biological action, physico-chemical properties etc. into the drug design process ${ }^{1-5}$. Prodrug designing is an important and fruitful area of research. Generally, in a prodrug, the carrier group or promoiety used is inert or nontoxic. However, in certain cases the prodrug consists of two pharmacologically active agents coupled together in the form of a single molecule so that each acts as promoiety for the other agent ${ }^{4-6}$. Such derivatives have been termed as mutual prodrugs. Mutual prodrugs exhibit excellent pharmacological activities due to the combined contributions by both components ${ }^{4}$.

In recent years, the incidence of bacterial and fungal infections has been increasing dramatically owing to different factors including an increase in the number of immunocompromised hosts ${ }^{7-9}$. The increasing incidences of resistance to a large number of antibacterial agents are becoming another major concern ${ }^{9-13}$. These points obviously indicate the need of more effective antimicrobial agents with a broad spectrum of activity. Nalidixic acid is effective against infections with gram-negative bacteria, but it is less effective against most of the gram-positive bacteria, whereas sulfanilamide is a broad-spectrum antibacterial agent and orally effective against Escherichia coli, Klebsiella species, Enterobacter species, Staphylococcus aureus, Proteus mirabilis and P. vulgaris $^{14,15}$.

In view of these observations and in continuation of our work on prodrugs ${ }^{5,6}$, it was considered worthwhile to synthesize a mutual prodrug comprising of nalidixic acid and sulfanilamide, with an aim of getting a useful drug, which may act with effectiveness against gram-positive and gram-negative bacteria (broad spectrum). An added advantage of using the mutual prodrug could be its sustained release and even low doses might be effective.

\section{MATERIALS AND METHODS}

\section{Synthesis}

Melting points were taken in open capillary tubes and are uncorrected. Microanalysis of the compound was done on Perkin-Elmer model 240 analyzer and the values were found within $\pm 0.4 \%$ of the theoretical values. ${ }^{1} \mathrm{H}$ NMR spectrum was recorded on Bruker spectropsin DPX-300MHz with tetramethylsilane as internal standard in solvent $\mathrm{CDCl}_{3}$. Mass spectrum was recorded on a Jeol JMS-D 300 instrument fitted with a JMS 2000 data system at $70 \mathrm{eV}$. Spectral data are consistent with the assigned structure. The progress of the reaction was monitored on TLC, which was performed on silica gel. Iodine chamber and UV-lamp were used for visualization of TLC spots. Dry solvents were used throughout the study. The reaction involved in synthesis is given in scheme 1 . 


\section{SOUTHERN BRAZILIAN JOURNAL OF CHEMISTRY SOUTH. BRAZ. J. CHEM., Vol. 222, No. 22, 2014}

\section{A. Husain, A. Ahmad and S. A. Khan}

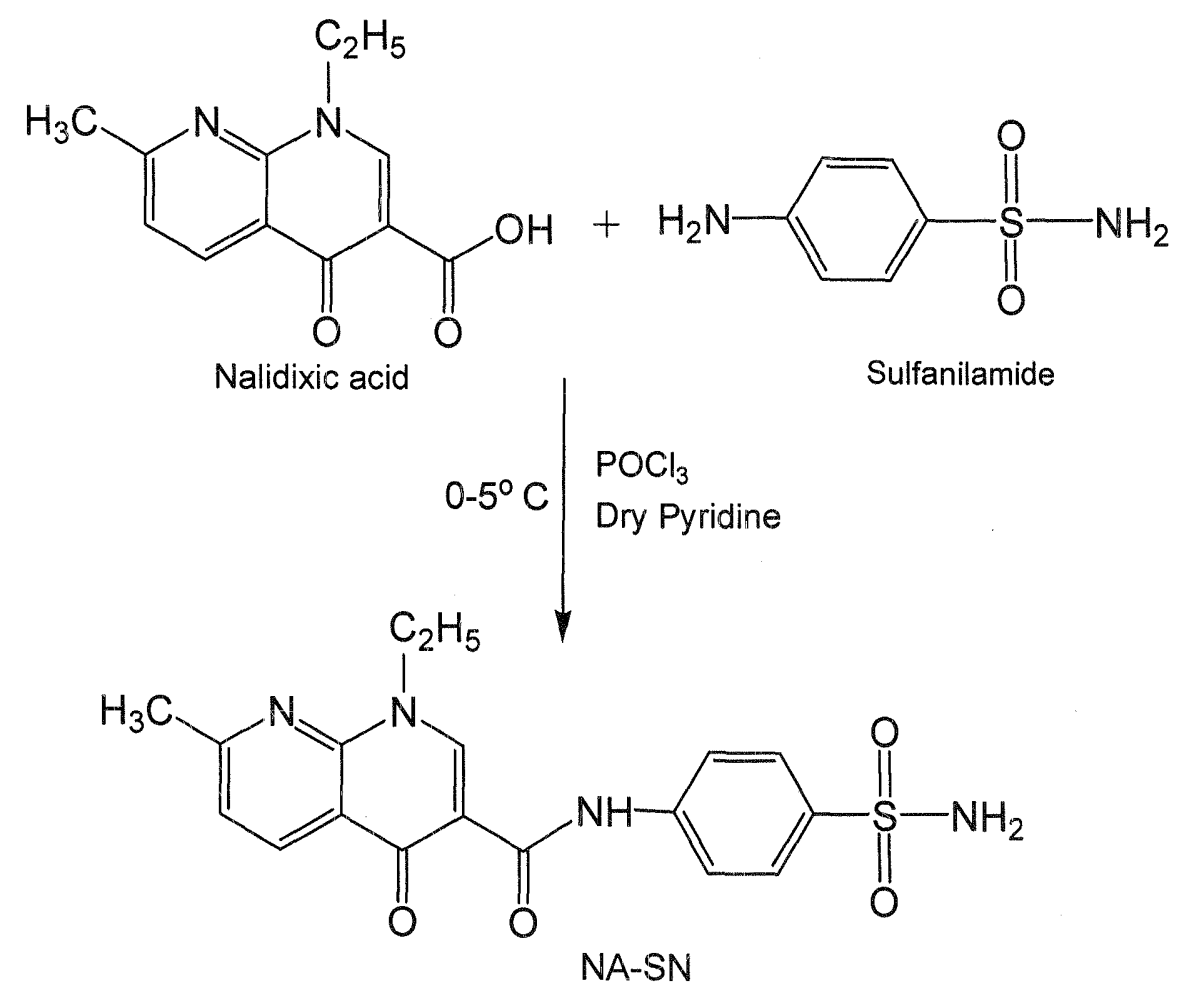

Scheme 1: Protocol for synthesis of mutual prodrug (NA-SN).

Synthesis of Mutual prodrug (NA-SN). Nalidixic acid (464 mg; $2 \mathrm{mmol}$ ) (1) was dissolved in dry pyridine $(5 \mathrm{~mL})$ and sulfanilamide $(344 \mathrm{mg} ; 2 \mathrm{mmol}$ ) (2) was also dissolved separately in dry pyridine $(5 \mathrm{~mL})$. Both the solutions were mixed together and stirred magnetically. Phosphorous oxychloride $(0.9 \mathrm{~mL})$ was added dropwise maintaining the temperature below $5^{\circ} \mathrm{C}$ while stirring. The contents were stirred for another half-hour and left overnight. It was poured into ice cold water and a solid mass separated out, which was filtered, washed, dried and crystallized from methanol to furnish TLC pure NA-SN (Scheme 1).

\section{Hydrolysis studies in aqueous buffers}

Hydrolysis kinetics of the synthesized mutual prodrug were studied in acidic and basic buffer. Acidic buffer ( $\mathrm{pH}$ 1.5) was prepared from conc. hydrochloric acid and basic buffer ( $\mathrm{pH}$ 7.4) was prepared from Tris base (Tris hydroxymethyl amino methane) of 0.2 $\mathrm{M}$ strength. Microcentrifuge tubes (1.5 mL capacity) were used for sampling purpose. In each tube $1 \mathrm{mg}$ of the drug was transferred and to it $1 \mathrm{ml}$ of the buffer was added. Samples were kept on a mechanical shaker at a temperature of $37 \pm 0.5^{\circ} \mathrm{C}$. The analysis was done at time intervals of $5 \mathrm{~min}, 30 \mathrm{~min}, 1 \mathrm{~h}, 3 \mathrm{~h}, 5 \mathrm{~h}, 7 \mathrm{~h}, 20 \mathrm{~h}$ and $50 \mathrm{~h}$ and subjected to HPLC analysis. Standard solutions were made in the solvent system, methanol: sodium hydroxide $(0.05 \mathrm{M})[3: 2 \mathrm{v} / \mathrm{v}]$. The HPLC system consisted of a U.V. 


\section{SOUTH. BRAZ. J. CHEM., Vol.22, No. 22, 2014}

Nalidixic Acid Mutual Prodrug

absorbance detector (programmable multiwavelength detector; Waters $490 \mathrm{E}$ ), data module (Waters $745 \mathrm{~B}$ ), pump and column (Bondapak $\mathrm{C}_{18}$ column, particle size $10 \mu \mathrm{m}$, $30 \mathrm{~cm}$ x $3.9 \mathrm{~mm}$ I.D; Waters). Mobile phase was consisted of methanol : acetonitrile : potassium dihydrogen phosphate $(0.015 \mathrm{M})[3: 2: 5 \mathrm{v} / \mathrm{v} / \mathrm{v}]$ of $\mathrm{pH} 2.5$ adjusted with ophosphoric acid. Detection was done at U.V. $255 \mathrm{~nm}$. The prodrug was eluted at the retention time of $10.1 \pm 0.2 \mathrm{~min}$. Nalidixic acid and sulfanilamide were eluted at $9.4 \pm 0.3$ min. and $3.2 \pm 0.2 \mathrm{~min}$, respectively.

\section{In-vitro antibacterial activity}

The bacterial strains gram positive; Staphylococcus aureus (MTCC 96) \& Bacilluus subtilis (MTCC 121) and gram negative: Escherichia coli (MTCC 1652) \& Klebsiella pneumonia (ATCC 13883) were used. The test was carried out according to the turbidity method $^{16,17}$. A solution of the compound was prepared in dimethylformamide (DMF) and a series of doubling dilutions prepared with sterile pipettes. To each of a series of sterile stoppered test tubes a standard volume of nutrient broth medium was added. A control tube containing no antimicrobial agent was included. The inoculum consisting of an overnight broth culture of microorganisms was added to separate tubes. The tubes were incubated at $37^{\circ}$ for $24 \mathrm{~h}$ and examined for turbidity. The tubes with highest dilution showing no turbidity was the Minimum Inhibitory Concentration (MIC).

\section{RESULTS AND DISCUSSION}

\section{Synthesis}

Nalidixic acid was condensed with sulfanilamide in dry pyridine in presence of $\mathrm{POCl}_{3}$ in a single step synthesis method. Usual work up of the reaction mixture followed by crystallization with methanol furnished the desired compound (NA-SN) as reddish brown-colored fine needles, Melting Point: $206-208^{\circ} \mathrm{C}$. Rf value: 0.81 (Toluene: Ethyl acetate: Formic acid, 5:4:1), Yield: $52.12 \%$ (Scheme 1 ).

Structure elucidation of NA-SN. The structure of NA-SN was established on the basis of ${ }^{1} \mathrm{H}$ NMR, Mass and elemental analysis results.

NMR spectrum: The ${ }^{1} \mathrm{H}$ NMR spectrum of the compound (NA-SN) showed a triplet and a quartet located at $\delta 1.62$ and $\delta 4.91$ arising from the methyl and methylene group of ethyl moiety in nalidixic acid. There was a singlet located at $\delta 2.88$ integrating for 3 protons of the methyl group of nalidixic acid skeleton. There appeared a singlet at $\delta 6.89$ integrating for 2 protons of the sulfonamide moiety $\left(-\mathrm{SO}_{2} \mathrm{NH}_{2}\right)$. A singlet located at $\delta 9.45$ could be accounted for the lone proton of the nalidixic acid system. Four protons of the $p$ disubstituted benzene ring of sulfanilamide moiety appeared as doublets at $\delta 7.49$ and $\delta$ 7.87. There could be located two ortho-coupled doublets at $\delta 7.64$ and $\delta 8.73$ arising from the two ortho-coupled protons of the nalidixic acid system. NH-proton of the sulfonamide moiety appeared as a singlet at $\delta$ 9.87. Mass spectrum: The mass spectrum of the compound showed a molecular ion peak located at $\mathrm{m} / \mathrm{z} 386$. The other two diagnostic peaks were located at $\mathrm{m} / \mathrm{z} 306$ and 215 . The fragmentation pattern has been shown in Chart-1.

Elemental analysis: The values were found within $\pm 0.4 \%$ of the theoretical values, $\mathrm{C}_{18} \mathrm{H}_{18} \mathrm{~N}_{4} \mathrm{O}_{4} \mathrm{~S}$, Calculated $\mathrm{C}, 55.95 ; \mathrm{H}, 4.70 ; \mathrm{N}, 14.50$, Found $\mathrm{C}, 55.72 ; \mathrm{H}, 4.58 ; \mathrm{N}, 14.34$. 


\section{SOUTHERN BRAZILIAN JOURNAL OF CHEMISTRY \\ SOUTH. BRAZ. J. CHEM., Vol. 22, No. 22, 2014}

\section{A. Husain, A.Ahmad and S. A.Khan}

51<smiles>CCn1cc(C(=O)Nc2ccc(S(N)(=O)=O)cc2)c(=O)c2ccc(C)nc21</smiles>

NA-SN; $m / z 386$<smiles>CCCCCCCn1cc(C=[O+])c(=O)c2ccc(C)nc21</smiles>

$\mathrm{m} / \mathrm{z} 215$

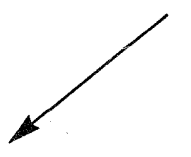

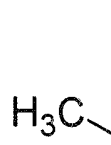<smiles>CI</smiles><smiles>CCC(C)(C)C</smiles><smiles></smiles>

$\mathrm{m} / \mathrm{z} 306$

Chart 1: Mass fragmentation pattern of the mutual prodrug (NA-SN).

\section{Hydrolysis study}

The hydrolysis studies were carried out in aqueous buffer so as to study whether the prodrug hydrolyze in aqueous medium and to what extent or not, suggesting fate of the prodrug in the system. Hydrolysis kinetics of the synthesized mutual prodrug (NA-SN) were studied in acidic buffer ( $\mathrm{pH}$ 1.5) and basic buffer ( $\mathrm{pH} 7.4)$. The hydrolysis of mutual prodrug to its parent components (nalidixic acid \& sulfanilamide) was not observed either in acidic or basic buffer suggesting that the drug was highly stable. In-vivo hydrolysis studies are under progress to ascertain its fate in the body.

\section{In-vitro antibacterial activity}

In-vitro antibacterial activity was carried out against the bacterial strains gram positive (Staphylococcus aureus \& Bacilluus subtilis) and gram negative (Escherichia coli \& Klebsiella pneumonia). Minimum inhibitory concentration was determined and results indicated that the compound (NA-SN) showed very good activity against $S$. aureus \& $E$. coli with $M I C-6.25 \mu \mathrm{g} / \mathrm{mL}$, and good activity against $B$. subtilis \& $K$. pneumonia (MIC$12.5 \mu \mathrm{g} / \mathrm{mL}$ ). In-vivo antibacterial activities are required to further ascertain its usefulness; which are under progress in our laboratories. 


\author{
Nalidixic Acid Mutusal Prodrug
}

\title{
Conclusion
}

An amide-based mutual prodrug (NA-SN) has been successfully synthesized by condensing nalidixic acid with sulfanilamide in a single step. The prodrug was found resistant to hydrolysis in acidic and basic buffer system at $\mathrm{pH} 1.5$ and 7.4 , respectively, indicating its stability. The prodrug showed significant in vitro antibacterial activity against the tested bacteria. It is expected that after in vivo hydrolysis (by amidases and/or other enzymes) the prodrug would break into its parent compounds which have established antibacterial activity. In vivo studies are in progress in our laboratories to establish the suggested hypothesis.

\section{REFERENCES}

1. Satyam. Prodrugs containing Bio-cleavable linkers, European Patent, 2007, 2075011.

2. Huq, F. J. Pharmacol. Toxicol. 2006, 1(4), 362.

3. Ohian, S.; Nanda, S.; Pathak, D. P.; Jagia, M. Int. J. Pharm. Sci. Res. 2011, 2(4), 719.

4. Bhosle, D.; Bharambe, S.; Gairola, N.; Dhaneshwar, S. S. Indian J. Pharm. Sci. 2006; $68: 286$.

5. Husain, A.; Khan, M. S. Y. Understanding biology using peptides 2006, 9(7), 477.

6. Husain, A.; Rashid M. South Braz. J. Chem. 2010; 18(18): 29.

7. Davies, J. Nature 1996, 383, 219.

8. Mirnejad, R.; Fallahi, S.; Kiani, J.; Jeddi, F.; Khoobdel, M.; Jonaidi, N.; Alaeddini, F. J. Biol. Sci. 2008, 8(2), 478.

9. Manikandan, S.; Ganesapandian, S.; Singh, M.; Kumaraguru, A. K.. Curr. Res. Bacteriol. 2011, 4(1), 9.

10. Mohammadi, M.; Ghasemi, E.; Mokhayeri, H.; Pournia, Y.; Boroun, H. Asian J. Biol. Sci. 2010, 3(4), 195.

11. Nafeesa, A.; Sheikh, M. A.; Haq, I.; Jamil, A.; Parveen, Z. J. Med. Sci. 2001, 1(3), 97.

12. Adeleke, E. O.; Omafuvbe, B. O. Res. J. Microbiol. 2011, 6(4), 356.

13. Chu, D. T. W.; Plattner, J. J.; Katz, L. J. Med. Chem. 1996, 39, 3853.

14. Anand, N. in Burger's Medicinal Chemistry, edited by M E Wolf, A WileyInterscience Publication, NewYork, 1979.

15. Northey, E. H. The sulfonamides and allied compounds, American Chemical Society Monograph Sereis, Reinhold, NewYork, 1948.

16. Kumar, R.; Prasad, D. N.; Sharma, S.; Silakari, O. Int. J. Biol. Chem. 2011, 5(3), 193.

17. Cruickshank, R.; Dugid, J. P.; Marmion, D. P.; Swain, R. H. A. Medical Microbiology, $2^{\text {nd }}$ volume, Churchill-Livingstone, Edinburg , London, 1975.

VISIT OUR SITE: http://www.sbjchem.he.com.br

The SOUTHERN BRAZILIAN JOURNAL OF CHEMISTRY (ISSN: 2674-6891; 0104-5431) is an open-access journal since 1993. Journal DOI: 10.48141/SBJCHEM. http://www.sbjchem.com

This text was introduced in this file in 2021 for compliance reasons.

(c) The Author(s)

OPEN ACCESS. This article is licensed under a Creative Commons Attribution 4.0 (CC BY 4.0) International License, which permits use, sharing , adaptation , distribution , and reproduction in any medium or format, as long as you give appropriate credit to the original author $(\mathrm{s})$ and the source, provide a link to the Creative Commons license, and indicate if changes were made. The images or other third-party material in this article are included in the article's Creative Commons license unless indicated otherwise in a credit line to the material. If material is not included in the article's Creative Commons license and your intended use is not permitted by statutory regulation or exceeds the permitted use, you will need to obtain permission directly from the copyright holder. To view a copy of this license, visit http://creativecommons.org/ licenses/by/4.0/. 